\title{
ДИНАМІКА КЛІТИННОЇ ЛАНКИ ІМУНІТЕТУ ПРИ ВИКОРИСТАННІ СОРБЦІЙНО-ТРАНСМЕМБРАННОГО ДІАЛІЗУ
}

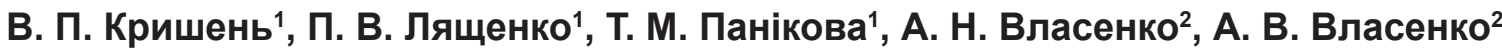

'Дніпропетровська медична академія,

²Дніпропетровське клінічне об'єднання швидкої медичної допомоги

\section{DYNAMICS OF CELLULAR IMMUNITY WHEN USING SORPTION-TPANSMEMBRANE DIALYSIS}

\author{
V. P. Kryshen ${ }^{1}$, P. V. Lyashchenko1, T. M. Panikova1, A. N. Vlasenko², A. V. Vlasenko \\ ${ }^{1}$ Dnipropetrovsk Medical Academy, \\ ${ }^{2}$ Dnipropetrovsk Clinical Association of Emergency Medical Aid
}

\begin{abstract}
Рефрерат
На основі аналізу результатів клінічного та лабораторного досліджень встановлено, що використання у комплексі лікування хворих з приводу поширеного перитоніту (ПП) сорбційно-трансмембранного діалізу для санації черевної порожнини дозволило досягти значної протекції CD8-лімфоцитів та зменшити тяжкість ендотоксикозу.

Ключові слова: перитоніт; поліорганна недостатність; CD8-лімфоцити; сорбційно-трансмембранний діаліз.

Abstract

Based on the analysis of clinical and laboratory investigations data revealed the use of sorption-transmembrane dialysis for sanitation of the abdominal cavity to achieve significant protection CD8-lymphocytes and reduce the appearance rate of endotoxemia in treatment of patients with widespread peritonitis.

Keywords: peritonitis; multiple organ failure; CD8- lymphocytes; sorption-transmembrane dialysis.
\end{abstract}

Перитоніт посідає одне 3 провідних місць в структурі хірургічних захворювань. Однією з найбільш складних проблем сучасної абдомінальної хірургії є лікування ПП та його ускладнень. В останні роки у значної кількості хворих виявляють занедбані форми перитоніту, що характеризуються агресивним перебігом, високою частотою післяопераційних ускладнень. Летальність при перитоніті станновить від 19 до 30\%, а на тлі прогресування поліорганної недостатності (ПОН) - досягає 80\%, не має тенденції до зменшення, що спричиняє великі економічні та медико-соціальні збитки. Однією з основних причин летальності при ПП $€$ ендотоксикоз [1]. Зменшення тяжкості ендотоксикозу безпосередньо впливає на поліпшення результатів лікування хворих з приводу ПП, що має важливе значення у профілактиці й лікуванні ПОН. Основним джерелом ендогенної токсемії при перитоніті є вогнище запалення в черевній порожнині [2]. Неможливість усунути вогнище інфекції під час однієї операції стало основою для розробки концепції етапного хірур- гічного лікування тяжких форм перитоніту. Лікувальний ефект одноразової санації черевної порожнини нетривалий, що свідчить про необхідність здійснення повторних, травматичних для хворих операцій санаційної релапаротомії.

Сучасні методи екстракорпоральної детоксикації у хворих при ПП, коли вже подолані та пошкоджені всі бар'єри фізіологічної детоксикації і спостерігають виражений ендотоксикоз та ПОН, забезпечують видалення токсинів з загального кровотоку [3]. У зв'язку з цим, зрозумілий інтерес до вивчення існуючих та розробки нових способів детоксикації, що запобігають тією або іншою мірою потраплянню токсинів у кровоток з вогнища запалення [4].

Важливу роль у прогресуванні запального процесу при ПП відіграє клітинна ланка імунітету, а саме CD8-лімфоцити, основною функцією яких $є$ посилення адаптивної імунної відповіді, яка полягає у розпізнаванні антигенів і активному утворенні антитіл.

Метою дослідження було вивчення змін кількості CD8-лімфоцитів при проведенні інтраабдомінального сорбційно-трансмембранного діалізу у хворих з приводу ПП.

\section{МАТЕРІАЛИ I МЕТОДИ ДОСЛІДЖЕННЯ}

Клінічна частина роботи основана на аналізі результатів обстеження й хірургічного лікування 108 хворих 3 приводу ПП. Причиною виникнення перитоніту у більшості хворих були перфоративна виразка шлунка та дванадцятипалої кишки, деструктивні форми гострого апендициту, защемлена грижа з резекцією кишки. Хворі госпіталізовані в хірургічний стаціонар у невідкладному порядку.

Після виконання основного етапу операції і усунення вогнища запалення всім хворим здійснювали санацію і дренування черевної порожнини, інтубацію тонкої кишки за допомогою тубажного зонда. Для подовженого діалізу черевної порожнини використовували дренажі власної конструкції (пат. України 78374).

Для надання сорбційних властивостей діалізу застосовували кремнеземний сорбент. Встановлено, що 
застосування сорбенту з метою дезінтоксикації у хворих при ПП за внутрішньочеревного шляху його введення у напівпроникні дренажі доцільне в абдомінальній хірургії. Розчин замінювали через кожні 12 год, що зумовлене сорбційною здатністю сорбенту. Після операції діаліз проводили постійно, припиняли при появі об'єктивних ознак усунення перитоніту.

У 50 хворих при ПП (основна група) після операції проводили сорбційно-трансмембранний діаліз; у 58 (група порівняння) у комплексі лікування трансмембранний діаліз не застосовували. Пацієнти обох груп порівнянні за статтю, віком, супутніми захворюваннями, характером основного патологічного процесу. Визначали абсолютну кількість лімфоцитів, що експресували CD8-рецептори, в 1 мкл крові.

Концентрацію CD8-лімфоцитів $0,3-0,7 \times 10^{9}$ в 1 л вважали нормальною. Порушення ланок клітинного імунітету оцінювали за вмістом у сироватці крові CD8-лімфоцитів. Збільшення або зменшення показників вважали ознакою прогресування запальної реакції на тлі ендогенної інтоксикації.

\section{ЛITEPATУPA/REFERENCES}

1. Apartsin KA, Lishmanov YuB, Galeev YuM, i dr. Bakterialnaya translokatsiya pri relaparotomii $v$ usloviyakh rasprostranennogo peritonita. Byul. SO RAMN. 2009;(2):95-9.

2. Alieva EA, Isaev GB, Gasanov FD. Puti povysheniya effektivnosti posleoperatsionnoy sanatsii bryushnoy polosti pri razlitom gnoynom peritonite (eksperimentalno-klinicheskoe issledovanie). Annaly khirurgii. 2008;5:57-9.

\section{РЕЗУЛЬТАТИ \\ ТА ÏХ ОБГОВОРЕННЯ}

Оскільки основним чинником несприятливого результату у хворих за ПП є порушення ланок клітинного імунітету на тлі токсеміі, найбільшу увагу при оцінці стану приділяли вмісту CD8-лімфоцитів в крові.

У хворих групи порівняння до операції і до 3-ї доби після неї відзначали збільшення відносно норми вмісту CD8-лімфоцитів на тлі прогресування системного запалення та ендотоксикозу. До операції, у 1-шу і 3-тю добу після неї концентрація CD8 лімфоцитів становила відповідно від 0,65 до 0,84 × 109 в 1 л, у середньому $0,73 \times 10^{9}$ в 1 л; від 0,74 до 0,92 $\times 10^{9}$ в 1 л, у середньому $0,81 \times 10^{9}$ в 1 л; від 0,85 до 0,79 × $10^{9}$ в 1 л, у середньому $0,92 \times 10^{9}$ в 1 л $(\mathrm{p}<0,05)$. На 5ту добу концентрація CD8-лімфоцитів також була більше початкової, становила від 0,86 до 1,09 × 109 в 1 л, у середньому $0,93 \times 10^{9}$ в 1 л; на 10ту добу - від 0,76 до 0,98 × $10^{9}$ в 1 л, у середньому 0,87 × $10^{9}$ в 1 л $(\mathrm{p}<0,05)$.

У хворих основної групи концентрація CD8-лімфоцитів у сироватці крові до операції та у 1-шу добу після неї була аналогічна такій в групі порівняння ( $\mathrm{p}=0,468, \mathrm{p}=0,312)$. У цей період на тлі прогресування системного запалення й ендотокси- козу концентрація цього показника збільшувалася

До операції, у 1-шу і 3-тю добу після неї концентрація CD8-лімфоцитів становила відповідно від 0,67 до $0,82 \times 10^{9}$ в 1 л, у середньому 0,73 $\times 10^{9}$ в 1 л; від 0,72 до 0,95 × 109 в 1 л, у середньому $0,80 \times 10^{9}$ в 1 л; від 0,83 до $1,07 \times 10^{9}$ в 1 л, у середньому 0,91 $\times 10^{9}$ в 1 л $(\mathrm{p}<0,05)$. Тільки на 5-ту добу концентрація CD8-лімфоцитів дещо зменшилася від 0,71 до 0,93 × $10^{9}$ в 1 л, у середньому $0,84 \times 10^{9}$ в 1 л; на 10-ту добу - становила від 0,73 до $0,95 \times 10^{9}$ в 1 л, у середньому $0,82 \times 10$ в 1 л $(\mathrm{p}<0,05)$. У пацієнтів основної групи на 5-ту та 10-ту добу після операції спостерігали більш стрімке зменшення концентрації CD8лімфоцитів у сироватці крові, ніж у групі порівняння. На нашу думку, це пов'язане з використанням запропонованого способу промивання черевної порожнини.

Таким чином, результати дослідження змін клітинної ланки імунітету, а саме CD8-лімфоцитів, свідчать про високу ефективність інтраабдомінального сорбційно-трансмембранного діалізу як способу прискорення процесу детоксикації у комплексі лікування хворих з приводу ПП.

3. Eryukhin IA, Bagnenko SF, Grigor'ev EG, i dr. Abdominalnaya khirurgicheskaya infektsiya: sovremennoe sostoyanie i blizhayshee budushchee $v$ reshenii aktual'noy klinicheskoy problemy. Infektsii v khirurgii. 2007;(1):6-11.

4. Rozenfeld LG, Moskalenko VF, CHekman IS, Movchan BA. Nanotekhnologii, nanomeditsina: perspektivy nauchnykh issledovaniy i vnedrenie ikh rezul'tatov $v$ meditsinskuyu praktiku. Ukrainskiy meditsinskiy zhurnal. 2008;5:63-8. 